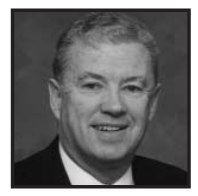

\title{
Schools as Centres of Change Not Centres of Blame: Constructing Bridges Between Policy and Practice
}

\author{
Dean Fink, Dean Fink Consulting Associates
}

\begin{abstract}
Many years ago, Hugh MacLennan (1945) described the relationship between French and English speaking Canadians as "two solitudes." This paper contends that there are "two solitudes" in education that threaten the very essence of state-supported education. It will argue that policy makers have made schools the centres of blame and have adopted policies that fail to account for the realities of schools, teachers and students. It will also suggest ways to bridge the gap between policy and practice and develop schools as centres of change.
\end{abstract}

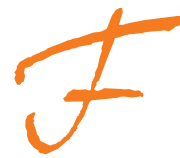

ourteen years ago, after many years as a teacher, principal and senior administrator in public education in the province of Ontario, I joined the ranks of educational consultants with the intent of providing advice and support to schools and school districts around the world. I suspect I began like most consultants with an experiential and academic background such as mine with the goal of informing others how it should be done, and of course blaming any failures to follow my advice on the ignorance and apathy of others. Fortunately, some early, rather humbling experiences taught me that my arrogant approach not only did not account for the different contexts in which others worked, but it also alienated those I was trying to help.

To survive in the competitive consulting field, I quickly realized that the most helpful support that outsiders like me can provide to others is to help them ask 
better questions about their contexts-to problem seek-to look at things from different perspectives. ${ }^{1}$ For it is out of asking better, more comprehensive, and more searching questions, that schools and school districts can avoid the "law of unintended consequences" and arrive at better answers to problems and issues in their local contexts. The law of unintended consequences suggests that for every policy initiative there will be unpredicted and unpredictable results-some good, some bad. By taking the time up front to ask the appropriate questions, those of us engaged in school improvement can minimize the "bad" consequences of school improvement efforts and address the crucial issues of students' learning.

The law of unintended consequences can be cruel. Let me give a few examples. I am sure that the Conservative government of Ontario under Mike Harris did not intend to unify its teachers into a broad coalition that staged a two-week strike and make them deeply disenchanted and suspicious of any government initiative when it imposed its reform agenda by blaming its teachers for most of the ills of society. I am sure successive British governments did not want to create teacher and leadership shortages that would cost great sums of recruitment money or to precipitate a serious morale issue among teachers (Earley et al., 2002). I am also sure that the United States did not intend to further exacerbate the gap between "have" and "havenot" children when it passed its No Child Left Behind legislation (Nichols \& Berliner, 2007; Kozol, 2005; McNeil, 2000).

I often ask the groups of educators I work with to identify paradoxes, ironies or oxymorons in their educational contexts. In many places for example, the term "school improvement" when attached to "top-down" policy initiatives is often considered an oxymoron. In virtually every country I've visited, these paradoxes, ironies and oxymorons reflect a deep disconnect between policy makers and the teachers and school leaders who have to implement them. We have in many countries "a dialogue of the deaf" between these two groups. In almost all cases, well-intentioned, highly motivated people, both policy makers and policy implementers, seek in their own ways to create the very best educational experiences for young people. Unfortunately, they have become so caught up in their own "context," "paradigm" or "mindset" that they are unable or unwilling to see the perspective of others, or to acknowledge that their way may not support students' learning. Many years ago, Hugh MacLennan (1945) described the relationship between French and English speaking Canadians as "two solitudes." I would submit that there are two solitudes in education in most countries and provinces or states that endanger the longevity of important changes and threaten to undermine the very essence of state-supported education. This dialogue of the deaf can exist between ministries of education and 
school districts and schools, district offices and its schools, or the principal's office and the teaching staff. The two solitudes have resulted in schools becoming the centres of blame when reform does not happen as the reform initiators envisage it, as opposed to schools as the centres of change where genuine and meaningful school improvement occurs.

\section{The Two Solitudes: How Schools Become The "Centres Of Blame"}

\section{Sources of Change}

When "the wall" came down in 1989, the international order of things changed profoundly. Before the fall of the Berlin Wall and the end of the Cold War, virtually all international and national policies pertained in some way to the confrontation between the "West" and the "East." As Friedman (1999) points out, these power Blocs were like two sumo wrestlers-pushing each other around amidst much grunting, groaning and ritualistic posturing. Now as the result of information technology and the disappearance of the "old rules" of international engagement, nations and states, to continue Friedman's sporting metaphor, are in 100-metre races against each other, but no sooner is one completed than another begins. Just as our economies, cultures and politics, for better or for worse, are becoming increasingly globalized and flattened (Friedman, 2007), so is education. Policy makers, aware of this shifting international terrain, must focus on policies that help their nation, province or state to participate and survive in a strange and somewhat chaotic game in which the rules keep changing. Much of the rhetoric I hear about education is that "we" (and you can fill in the "we") must improve our educational system so that "our" nation, province, state or district can compete in this changing economic world. The underlying premise for most educational change policies predicated on economic expediency, however, rests on a flawed assumption that increasing students' achievement based on standardized test scores somehow translates into increased national productivity. The reality is that a nation's standing on international educational league tables usually bears little relationship to national competitiveness (Cuban, 2004). For example, Canada is rated near the top on recent Program for International Student Assessment (PISA) studies in literacy (IES, 2007), mathematics and problem solving, but thirteenth in international competitiveness (IMD, 2007). The most productive economic force in the world at the moment, the United States, is at or below the median on most international comparisons of educational attainment. This logical fallacy leads many 
policy makers to speak in the language of educational failure - that is, "our (and you can fill in the 'our') educational system has failed our young people and our economy." This demoralizing message does little to motivate educators to improve their practices. You cannot make winners by calling them losers (2002). I think a better argument and a more realistic one is that our system has delivered what we historically wanted it to deliver, but now it is dated and must change. Not only is this a more accurate reflection of the global situation, but also it would encourage a more enthusiastic and supportive response from the people who have to implement changeteachers and leaders.

Unlike policy initiators who often see children as mere statistics, policy implementers face the reality of promoting the learning of a specific group of children, with all their diversity and complexity. Moreover, each context creates a set of factors with which policy implementers must contend, and policy initiators are often unaware or unimpressed. Poverty, for example, does affect children's learning (Berliner, 2006). Efforts by some policy makers to obfuscate this reality are unhelpful at best and downright dishonest at worst. Students do not come in the neat little categories that some policy makers and academics tend to create. Teachers not only face issues of socioeconomic class, but also diversity of race, ethnicity, gender and sexuality. Moreover, each child comes equipped with his or her own set of needs, interests and abilities. While policy makers ask how we are going to improve our system to compete in the emerging economy, teachers ask how we are going to get this particular reluctant child to read and write. The goals may be similar but the understanding of each other's reality appears to be lacking.

To policy makers and many academics, teachers are often viewed as technicians.

Central to this notion of teaching is the belief that if procedures are correctly defined, clearly detailed and correctly monitored, most major teaching decisions can and should be prescribed through policy mandates that alter school schedules, programs, assessment, and teaching responsibilities.... When a technical view of teaching is influential, reformers assume that educators have the capacity and ability to teach in different and more effective ways but are either lazy, unknowledgeable, unfocused or resistant to change (Bascia \& Hargreaves, 2000, p. 5).

Such technical approaches may work when the purpose is to teach a narrow band of low level skills, but to teach each child a rich, intellectually challenging curriculum, however, requires teachers who are able to: 
- deal with the complexity of continually updating their knowledge of subject matter, child development, and assessment strategies

- work collaboratively with colleagues, and engage in positive ways with the social-emotional lives of each child in their care (Hargreaves and Fink, 2000)

- create meaning for themselves and their students in the learning process

In comparison to other professions, there is clear evidence that teaching ranks high in task complexity (Rowan, 1994). The best way to enhance students'learning, therefore, is to invest in teachers' learning (Stoll, Fink \& Earl, 2003). The evidence is very clear that the change process driven by coercive testing regimens and external inspections is failing (Nichols \& Berliner, 2007; BBC, 2007). There are better ways.

\section{Orientation to Change}

Policy makers removed from this day-to-day reality tend to espouse broad philosophies based on their own experience, ideological inclinations or educational background. Whether it is unquestioning adherence to the wisdom of the market as the solution to all problems, or the unwavering adherence to progressive approaches to curriculum and teaching, the clear evidence is that "one size does not fit all." Nonetheless, policies that are often based on political theories are pursued with zealous certitude with little real thought as to the consequences for "real" students in "real" schools with "real" teachers.

Policy implementers have a different orientation to the change process from policy initiators. Teachers, in particular, and principals tend to operate based on the "practicality ethic" - does it work for my students in my classroom, or for my students in my school (Doyle \& Ponder, 1977). In my consulting work, change efforts have succeeded where teachers believe the innovations that have been introduced make a difference to them and their students in their classrooms. My involvement with the Change Over Time study in Ontario indicates that teachers tend to retreat to their departments and classrooms in the face of multiple changes and have difficulty looking at change on a school-wide basis, let alone systemic change (Hargreaves \& Goodson, 2006). Indeed in this study, my colleagues and I saw teachers withdraw from school-wide committees, extracurricular activities and adopt a siege mentality as they experienced one change after another. Similarly, many of the very best leaders and teachers retired early because of their profound disenchantment with the directions of the top-down mandates. The loss of experience and wisdom is showing up daily as inexperienced and unprepared leaders learn by trial and error. There is a 
growing leadership crisis in Canada, the United Kingdom and many American states because competent people are either leaving the profession or choosing alternative career paths (Williams, T., 2001; Early et al., 2002; Fink, 2005). As I will argue later, investment in leadership is a key to school improvement. In addition, schools have jettisoned school development plans and other school improvement strategies to manage the onslaught of often ill-conceived government changes. Interestingly, outside mandates do appear to energize those few schools that have had a very limited history of school improvement. It would appear that mandated "top-down reform" is inversely related to a school's prior record of school improvement (Hargreaves et al., 2000).

\section{Intellectual Paradigm}

Policy makers frequently operate from a very rational/linear/intellectual paradigm. They consider education a technical exercise that can be improved by a mandate here, a new policy there, or a plethora of accountability procedures. They define "what" the students are to learn, divide the learning into convenient chunks, establish time frames, develop a testing regimen, organize suitable materials, and tell teachers how to achieve predetermined targets. As well, they oblige teachers to enroll in in-service sessions to learn the correct way to do what is required and initiate plenty of measures to check that the teachers faithfully carry out the policy makers' designs. These strategies are all rather straightforward, logical, linear and quite consistent with western intellectual thought for the past 400 years. René Descartes said, "I think therefore I exist" and set in motion an intellectual revolution that underpins all of our major institutions, especially schools. Reason and rationality have become the predominant ways of knowing. Many of our businesses, schools and other social organizations reflect this way of thinking (Mintzberg, 2004). For example, a student who attends virtually any secondary school is looked upon not as a whole living, breathing, feeling person but rather in terms of his or her parts-the history part, the science part, the mathematics part and so on. The student proceeds in a perfectly linear, logical way from class to class, each of which is organized into a period of equal length regardless of the learning program. The student then progresses in assembly-line fashion from year to year until he or she leaves school. This has proven to be a very efficient way to educate large numbers of students. Its effectiveness, however, is another matter.

Since the early 1970s, the newer sciences such as quantum physics, molecular biology, Gestalt psychology and ecology have challenged the conventional rationallinear paradigm. Their proponents have argued that rationality must be balanced by 
an ecological approach which looks at human and natural systems holistically, instead of just knowing them through their parts and attempting to understand their interrelationship and connections within larger systems (Capra, 1983, 2002). Within this paradigm, students are seen as whole persons who operate in particular contexts and are only knowable and therefore teachable if one is conversant with the patterns which affect the individual's life. Implementers face a non-rational, non-linear, complex and some would even suggest chaotic reality. Unless policy makers are prepared to understand the policy implementers' reality - the influence of context, micro-politics, school culture, the emotions of teaching and learning and leadership styles on educational change - school systems are, in the words of Michael Fullan, "doomed to tinkering" (1991). Policy makers need to understand more than just the content of the changes they mandate; they must grasp the complexities and subtleties of the change process (Tyack \& Tobin, 1994; Tyack \& Cuban, 1995; Stoll \& Fink, 1996; Hargreaves, 2004). To bridge the two solitudes, policy makers need to address both the content and processes of change simultaneously (Sergiovanni, 2000).

\section{Change Strategy}

As mentioned, the prevailing change strategy emanating from government offices throughout the world has been a top-down compliance model. The pattern in North America has been fairly consistent-first manufacture an educational crisis by naming, blaming and shaming educators for real and alleged failures of the system; design a curriculum with more content and "higher" standards; change structures of governance to reduce local political control, and reduce funding in the name of efficiency. Since teachers and other educators are perceived to be the source of most problems, they must be obliged to comply with mandates by elaborate and usually expensive accountability measures. Simply stated, change is not something done "with" educators; it is done "to" them. More recently, the apparent failure of such policies has gradually led to policies that are no less directive, but at least recognize the complexity of the change process and the role of teachers and leaders. Ironically, the perceived problem is also the solution.

There is unfortunately, not a great deal of room in most of the reform agendas internationally for creativity, imagination, flexibility and innovation. Clearly, knowledge workers must possess these qualities to function effectively in a changing economic climate. This raises an interesting paradox. On the one hand, schools must prepare their charges for a world of complexity and indeterminacy. The students in our schools today must be more creative, imaginative, resilient, and persistent than students in the past have been. On the other hand, the people who must prepare 
students in this way are often treated like skilled tradespeople by being required to deliver pre-packaged programs designed to assist student achievement on tests which in many cases assess relatively low level skills and knowledge.

\section{Success Criteria and Change}

The two solitudes assess the results of reform in quite different ways. Policy makers expect clear measurable evidence that change has occurred. They tend to want policies and practices that are both efficient and faithful to the intent of the policy designers (Cuban, 2004). A second criterion for success from the policy makers' perspective is the fidelity with which the reforms are carried through in the classroom. Are the implementers acting in accordance with the spirit of the change? The third criterion for policy makers is popularity (Cuban, 2004). Are the changes politically popular? Often, the pressured climate created by policy makers is to provide tangible results before another election. I would argue that the penchant for standardized testing has swept the world because it is efficient, popular, inexpensive, supported by powerful vested interests, and can be carried out with fidelity. To the teachers in the classroom, success is not an array of disembodied statistics on tests of questionable utility; they judge the efficacy of a change initiative on whether it can be adapted to their individual context.

\section{Conceptions of Time}

Another source of the two solitudes is based on differing concepts of time. Policy makers tend to operate within a monochronic time frame, which is concerned with doing one thing at a time in discrete segments, in an organized and scheduled manner. Most government, school and district administrators operate on monochronic time. Also, most Western organizations operate on monochronic time because this is the traditional way to get business done and achieve results (Hargreaves, 1994).

Teachers, particularly primary teachers, operate on polychronic time. According to Hargreaves (1994), this "is a world deeply grounded in intense, sustained, and subtly shifting interpersonal relationships among large groups of children and between these children and their teacher" (p. 104). Principals in many primary schools, in particular, also tend to operate on polychronic time. Days are often a series of unrelated events, crises, and planned activity. Misunderstanding and poor policy implementation can occur when policy makers who tend to operate on monochronic time fail to consider the polychronic concepts of time of the people who have to implement changes. 


\section{Bridging the Gap:Schools as the Centres of Change}

While the preceding discussion has tended to dichotomize the worlds of the "policy maker" and the "policy implementer," the challenge for people involved on both sides of this divide is to create and maintain bridges of understanding between their two realities as the way to build a "state of the art" educational system. There is an old proverb that states, "You think because you understand one you must understand two, because one and one make two. But you must also understand and." In the remainder of this paper, I would like to offer suggestions as to what the "and" is in education - the issues that both policy makers and policy implementers should focus on.

My writing partner, Louise Stoll, in her inaugural address at the University of Bath in the United Kingdom, asked a fundamental question: How good is your local school, really? (Stoll, 2001). This is a question that all the stakeholders in a school and educational system should address collaboratively. It focuses everyone's attention on the "and." Professor Stoll then asked seven provocative questions to address the "goodness" of a school.

- Is your school preparing its students for their future or our past?

There is an old Hebrew saying, "Do not limit your children to your learning, for they were born in a different time." A starting point is to ask: "What do we want our children to be?" Once we have agreed on what we want our children to be (e.g., literate, numerate, creative, inquisitive, tolerant, patriotic, kind and just), we can then ask the second question.

- Does the school do the right things?

If we want students to be literate, for example, what does each teacher do to promote this goal? How do we build a language program across the curriculum? What does the science or mathematics teacher do to promote language development? Do we have a coherent school-wide policy on language teaching? Moreover, have we examined proven approaches to language development? Are we aware of the most effective ways to promote language learning?

- Is it about learning?

While much of the focus of reform efforts has been on improved teaching, we have ignored the learner. We now know that students construct their knowledge-that they filter it through their preexisting experiences, 
emotions and understandings. "Deep learning and teaching are also cultural and emotional processes. They entail contextualizing students' learning in what they have learned before, in what other teachers are also teaching them, and in students' own cultures and lives. This deep contextualization of learning which gets students engaged ... is a cultural and not just a cognitive task" (Hargreaves \& Fink, 2000, p. 30).

- Does the school have an improvement culture?

The simplest definition of culture is the "way we do things around here." Culture is what happens when no one is looking. I think of culture as the rules that the principal does not have in his or her book of school procedures. These are the "real" rules of the school- "you primary teachers stay in your area, we will deal with the senior students"; "we never take work home on the weekend"; "the parents are sending the wrong children again this year." In Changing Our School, Louise Stoll and I (Stoll \& Fink, 1996) outlined 10 cultural norms of improving schools that lead to an improved culture:

\section{Norms of Improving Schools}

1. Shared goals-"We know where we're going"

2. Responsibility for success-"We can succeed"

3. Collegiality-"We're working on this together"

4. Continuous improvement- "We can get better"

5. Lifelong learning - "Learning is for everyone"

6. Risk taking-"We learn by trying something new"

7. Support- "There's always someone there to help"

8. Mutual respect- "Everyone has something to offer"

9. Openness-“We can discuss our differences"

10. Celebration and humour-"We feel good about ourselves"

- Does it have internal capacity?

Is the school a professional learning community? Is it capable of challenging the old?-Evaluating the new?-Implementing and sustaining important changes? Professional learning communities are just what the name implies: 
Communities where diverse people have a shared commitment to common practice, to each other in pursuing that purpose, and to acknowledge an inclusion of minority views in collective decision making.

Learning of the students, the adults and the organization more generally. The learning is deep and not superficial and the community's first response to problems and challenges is "What do we know about this?"

Professional in how they value grown-up norms of difference, disagreement and debate about the best ways to identify and implement needed improvements and how they promote, value, and bring together formal evidence (Hargreaves \& Fink, 2007, p. 126).

- Does it have good support systems?

Schools are nested in larger systems. Without support from higher levels of the educational hierarchy and from individual communities, it is very difficult for schools to succeed against the odds-although some do. As my previous discussion of the "Two Solitudes" indicates, policies pursued with the intent of "helping" often fail to consider the uniqueness of each context. Simply stated, one size does not fit all. Some schools will need more support than others.

\section{- Does it help children to progress?}

Are the students making progress as a result of what is being done? This raises the question: "Progress on what?" How do we know? The entire issue of evaluation of student performance is a huge topic but how do we avoid "letting the testing tail wag the teaching-learning dog." Are the evaluation procedures evaluating what is valued?

- Does the school have quality leadership?

It seems to me that there is only one purpose for school leaders and that is to enhance the learning of students, both formal and informal. I constantly challenge leaders to ask one question of their schools' decisions, practices, customs or policies: "Do they enhance the learning of their students?" This question powerfully focuses attention on what matters in a school. The very best of the thousands of educational leaders with whom I have interacted over the years were, and most still are, passionately, creatively, obsessively and steadfastly committed to enhancing "deep" learning for students-learning for understanding, learning for life, 
learning for a knowledge society (Fink, 2005). Successful businesses that sustain success over time invest heavily in succession management to ensure a continuous supply of the types of leaders that will take their organization forward. These businesses look for people with the potential to learn the key aspects of the business and continue to learn and grow, rather than just focusing on existing competencies. In education and much of the public service, we tend to advertise the job as it exists now, rather than taking the long-term view. Succession management involves the identification, recruitment, development, selection, placement, ongoing support, and appraisal of existing and potential leaders. Sadly, many educational jurisdictions see this process as an expense rather than an investment. These ideas are developed in depth elsewhere (Stoll, Fink \& Earl, 2003; Fink, 2005; Hargreaves \& Fink, 2006).

\section{Some Advice for Policy Makers}

Let me return to the idea that effective schools blossom in effective school systems, and make a couple of suggestions to those that are charged with operating networks of schools.

- Think systemically-Schools in many places are overwhelmed by changes and projects thrust upon them by well-meaning change agents. They suffer from "projectitis." Since most educational jurisdictions operate as bureaucracies, one division is often unaware of what another division is doing. They need to understand what is happening on the ground-to teachers, students and parents. Schools need pressure to change but also support to respond to change. It is the judicious application of pressure and support that yields the best results. Too much pressure creates a siege mentality in the schools-too much support promotes apathy and contentment.

- Coalitions not coercion-The educational stakeholders need to unite around important moral purposes for schooling. This implies enrolling governments, unions, community groups and whatever other groups strive for a shared set of goals on behalf of children. We have successful models in the civil rights, environmental and feminist movements. It is 
now time for the "learning movement." "Finger pointing" and "naming, shaming and blaming," as has been the practice in some school systems, may bring short-term political gain but in the last analysis contribute little to the learning of students.

- Networks not markets-The strategy of choice in many countries to improve schools is to force schools to compete for students and use the logic and competition of the marketplace to force changes for schools to survive. This absolves governments and taxpayers of the problem and the guilt. Markets are wonderful places and are excellent at producing wealth. Markets, however, do a terrible job of distributing wealth. The clear evidence is that market principles applied to education create wonderful schools for a few (usually the more privileged) and mediocre or worse schools for the vast majority. If schools are to compete, it should be as united and networked units against the forces of poverty and injustice.

- It's about learning and it's about time-Focus the resources on improving students' learning, not their test scores or other artificial means of intellectual accounting. To achieve growth in student learning, investment in teachers' learning and leaders' learning is needed. The goal is to have every school a learning community.

\section{Conclusion}

The challenge for those of us who want to improve education for all children for the future is to create and maintain bridges of understanding between these two realities as the way to build a "state of the art" educational system. Regardless of our roles, most of us are probably both policy makers and policy implementers. Policy makers attend to what Sergiovanni (2000) calls the "systemworld."This is the world of structures, accountability, policies and protocols. These provide the order and direction for complex organizations. "In schools leaders and their purposes, followers and their needs, and the unique traditions, rituals, and norms that define a school's culture comprise the lifeworld" (Sergiovanni, 2000, p. 61). Change efforts that focus only on the "systemworld" or the content of change, and ignore the "lifeworld" or processes of change, will shine brightly as long as the pressure to change is maintained, but over time fade away as so many change efforts have in the past. Only policy makers and policy implementers who understand each other's world, and work together to 
enhance the educational experiences of all students in their care, can address educational change productively. It was Neil Postman, the late American scholar, who said, "Children are the living messages that we send to a time we will not see" (Postman, 1984 , p. xi). There is no higher calling —as educators we shape the future.

\section{Notes}

1. To date I have worked in 30 different countries including Canada, the United States, United Kingdom, Australia and New Zealand.

\section{References}

Bascia, N. and Hargreaves, A. (2000). The Sharp Edge of Educational Reform. Dordrecht, The Netherlands: Kluwer.

Berliner, D. (2006). Our impoverished view of educational reform. Teachers College Record, 18(6), 949-995.

BBC (2007). School literacy scheme attacked. Retrieved November 7, 2007, from http://news.bbc.co.uk/2/hi/uk_news/edu cation/7073275.stm

Capra, F. (1983). The Turning Point: Science, Society, and the Rising Culture. New York: Bantam Books.

Capra, F. (2002). Hidden Connections: A science for sustainable living. New York: Anchor Books.

Cuban, L. (1998). How schools change reforms: redefining reform success and failure. Teachers' College Record, 99(3), 453-477.

Drake, S. (1995). Connecting learning outcomes and integrated curriculum. Orbit, 26(1), 28-32.

Doyle, W., and Ponder, G. A. (1977). The practicality ethic in teacher decision-making. Interchange, 8(3), 1-12.

Earley, P., Evans, J., Collarbone, P., Gold, A., and Halpin, D. (2002). Establishing the Current State of School Leadership In England: Research report No. 336. London: Department for Education and Skills.
Fink, D. (2005). Leadership for Mortals. Thousand Oaks, CA: Corwin.

Fink, D. (2000). Good Schools/Real Schools: Why school reform doesn't last. New York: Teachers' College Press.

Friedman, T. (2000). The Lexus and The Olive Tree. New York: Anchor Books.

Friedman, T. (2007). The World Is Flat: A brief history of the $21^{\text {st }}$ century. Toronto: Douglas and Mclntyre.

Fullan, M. G. (1991). The New Meaning of Educational Change. New York: Teachers' College Press.

Hargreaves, A. (1998). The emotional politics of teaching and teacher development: with implications for educational leadership. International Journal for Leadership in Education, 1(4), 316-336.

Hargreaves, A. (1994). Changing Teachers, Changing Times. London: Cassell.

Hargreaves, A. and Fink D. (2006). Sustainable Leadership. San Francisco, CA: Jossey- Bass.

Hargreaves, A. and Goodson, I. (2006). Educational change over time? The sustainability and non-sustainability of three decades of secondary school change and continuity. Educational Administration Quarterly, 1(42), 3-41. 
Hargreaves, A. and Fink, D. (2000). The three dimensions of education reform. Educational Leadership, 57(7), 30-34.

IES. Program for International Student Assessment. Retrieved November 7, 2007, from http://nces.ed.gov/pubsearch/get pubcats.asp? sid $=098$

IMD (2007). World Competitive Yearbook. Retrieved November 7, 2007, from http://www.imd.ch/research/publications /wcy/announcing.cfm

Kozol. J. (2005). The Shame of The Nation: The restoration of apartheid schooling in America. New York: Crown.

MacLennan, H. (1945). Two Solitudes, New York: Duell, Sloan and Pearce.

McNeil, L. (2000). Creating new inequalities. Phi Delta Kappan, 81(10), 729-734.

Mintzberg, H. (2004). Managers not MBAs: $A$ hard look at the soft practice of managing and management development. San Francisco, CA: Berrett-Koehler.

Nichols, S. and Berliner, D. (2007). Collateral Damage: How high stakes testing corrupts American schools. Cambridge: Harvard University Press.

Postman, N. (1984). The Disappearance of Childhood. New York: Vintage Books.

Rowan, B. (1994). Comparing teachers' work with work in other occupations: notes on the professional status of teaching. Educational Researcher, 23(60), 4-17.

Saul, J. R. (1993). Voltaire's Bastards: The Dictatorship of Reason in the West. Harmondsworth: Penguin.
Secretan, L. (1996). Reclaiming the Higher Ground: Creating organizations that inspire the soul. Toronto: Macmillan.

Sergiovanni, T. (2000). Changing change:Toward a design and art. Journal of Educational Change, 1(1), 57-75.

Stoll, L. (2001). How good is your local school, really? Inaugural Address. Bath: University of Bath, U.K.

Stoll, L, Fink, D. and Earl, L. (2003). It's About Learning and It's About Time. London: Routledge/Falmer.

Stoll L. and Fink, D. (1996). Changing Our Schools: Linking School Effectiveness and School Improvement. Buckingham: Open University Press.

Tyack, D. and Cuban, L. (1995). Tinkering Toward Utopia: A century of Public School Reform. Cambridge, MA: Harvard University Press.

Tyack, D. and Tobin, W. (1994). The Grammar of schooling: why has it been so hard to change? American Educational Research Journal, 31(3), 453-479.

Williams, P. (2002). The Paradox of Power. New York:Warner/Faith, p. 88.

William, T. (2001). Unrecognized Exodus, Unaccepted Accountability: The looming shortage of principals and vice principals in Ontario public school boards. Toronto: Ontario Principals Council. 


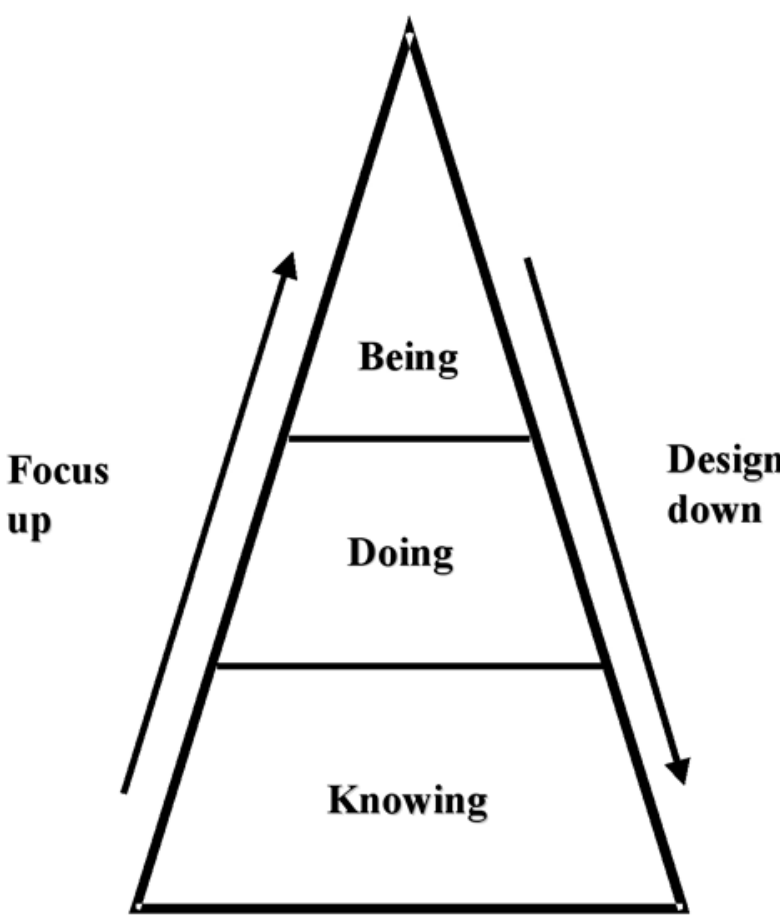

\section{Implications}

Fig. 1

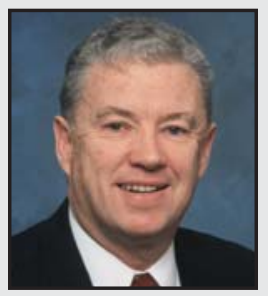

Dean Fink is presently an educational development consultant. He is a former teacher, principal and superintendent with the Halton Board of Education in Ontario. In the past fourteen years Dean has made presentations or conducted workshops in 30 different countries. He is the author or co-author of five books. His most recent books are Sustainable Leadership with Andy Hargreaves for Jossey-Bass Press (2006), and Leadership for Mortals: Developing and sustaining leaders of learning for Corwin Press (2006). 